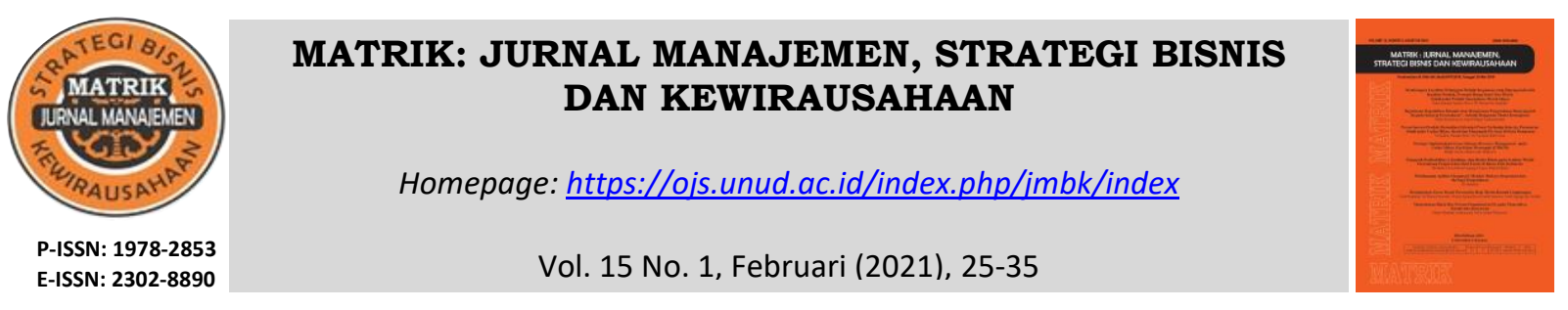

\title{
Building The Character of The Local Wisdom Perspective in The Press Industry
}

\author{
Ni Nyoman Diliyanti'), Ni Nyoman Sunariani' ${ }^{2)}$, Ni Made Widnyani'3), \\ Ni Luh Darmayanti ${ }^{4}$ \\ ${ }^{1,2)}$ Magister Manajemen, Universitas Pendidikan Nasional, Denpasar \\ 3) Universitas Bali Internasional \\ 4) Politeknik Transportasi Darat Bali \\ email: ninyomandiliyanti@gmail.com
}

\section{DOI : https://doi.org/10.24843/MATRIK:JMBK.2021.v15.i01.p03}

\begin{abstract}
Character is a mental or moral strength, that is the driving force, and differentiates it from other individuals. Character needs to be planted in the company to create human resources with character and ready to adapt well in order to development the company. Local wisdom can be used as an alternative in building the character of human resources (HR), because local wisdom is the noble values possessed by each region which are upheld by the values and meanings contained therein. Building character based on local wisdom will have a meaning when it is based on universal values that are rooted in the culture. One of the local wisdoms in Bali is the concept of Tri Kaya Parisudha. Tri Kaya Parisudha are three ethical teaching concepts that are controlled and harmonized, namely thoughts (manacika), words (wacika), and actions (kayika). Human character in the era of globalization should be assessed from the aspect of attitude or character, without prejudice to the numerical or numerical aspects of the assessment, seen as relevant as an indicator in building the character of human resources.
\end{abstract}

Keyword: human resource character, local wisdom, tri kaya parisudha

\section{Membangun Karakter Perspektif Kearifan Lokal Di Industri Pers}

\begin{abstract}
ABSTRAK
Karakter merupakan kekuatan mental atau moral, akhlak atau budi pekerti yang menjadi pendorong dan penggerak, serta membedakannya dengan individu lain. Karakter perlu ditanamkan dalam perusahaan untuk mewujudkan manusia yang berkarakter dan siap beradaptasi dengan baik demi memajukan perusahaan. Kearifan lokal dapat dijadikan alternatif dalam membangun karakter sumber daya manusia (SDM), karena kearifan lokal merupakan nilai-nilai luhur yang dimiliki oleh masing-masing daerah yang dijunjung tinggi nilai serta makna yang terkandung didalamnya. Membangun karakter berbasis kearifan lokal akan memiliki makna ketika dilandasi atas nilai-nilai universal yang mengakar dalam budaya itu dibangun. Salah satu kearifan lokal di Bali adalah konsep Tri Kaya Parisudha. Tri Kaya Parisudha merupakan tiga konsep ajaran etika yang dikendalikan dan diselaraskan yaitu pikiran (manacika), perkataan (wacika), dan perbuatan (kayika). Karakter manusia pada jaman globalisasi sudah selayaknya dinilai dari aspek sikap atau karakter, tanpa mengenyampingkan aspek penilaian yang berupa angka atau numerik, dipandang relevan sebagai indikator dalam membangun karakter SDM.
\end{abstract}

Kata kunci: karakter SDM, kearifan lokal, tri kaya parisudha 


\section{PRELIMINARY}

The development of information technology requires Human Resources (HR) to continue to develop themselves proactively. Of course, in this development HR will experience a change, both in religion and the character of HR itself. Therefore, it is expected that HR can master technology quickly, be adaptive, responsive in dealing with technological changes and have good character. In order for companies to be able to continue to survive in the competition, technology dominance alone is not enough if it is not supported by reliable human resources. Humans as God's creatures who have the highest degree compared to other God's creatures make humans have many advantages. The advantages that humans have are related to the mind. Through good thoughts will lead humans to say or do good, so that humans can regulate the movement of aspects of communication and aspects of behavior. It is through the style of communication and the motion of human behavior that the human character itself can be reflected.

To build a good HR character, requires careful and careful preparation, this is related to the HR character that a company wants to build. Preparing employees who are able to compete is one of the leadership tasks. Building identity/character requires the role of all components from family, educational institutions, government and mass media. One of the components that has received the sharpest attention lately is the mass media. Mass media is a means of delivering information, both real and just opinions or ideas. As a medium for forming public opinion, the mass media through its news and information are believed to be able to influence the character of its viewers.

One of the press industries in Bali is Bali Post. Bali Post is a daily newspaper in the provincial capital that claims to be the "Pancasila Practitioner Bearer" and is the largest daily newspaper in Denpasar City and is one of the dailies with the largest circulation in Bali. In order to build and improve the character of employees, the quality of employees is very much considered by the editors of Bali Post. This is evident from the many awards that Bali Post gets every year. The award that is almost every year won by Bali Post is from the United Press Association (SPS). Again, Bali Post won the Indonesia Print Media Award (IPMA) for the best national newspaper category 2020 (Bali Post, 2020). In addition, in 2018 an award was also given to Bali Post by the National News Agency (LKBN) Antara Bali Bureau as a partner who has provided the best cooperation so far. From the many awards that have been received, according to the chief editor of the Bali Post (Mr. Dira Arsana) said that the character of employees is the main factor in determining the quality of a company engaged in mass media.

However, on the one hand, anxiety occurs in the midst of a lot of competition in the mass media which is increasingly emerging when information technology is advancing rapidly. The form of this anxiety is about the moral degradation of human resources. One of the efforts that have long been echoed to minimize and at the same time overcome moral degradation is to build character through character education in order to be able to improve the character of human resources so as to create good quality human resources. Human resources with character will influence other elements that are requirements for the formation of qualified and adequate human resources, both technically and non-technically, which will have more opportunities to be achieved. With a strong character, HR will never give up and always work smart and hard, be disciplined, develop the spirit of mutual cooperation in mobilizing all their potential, to bring progress and glory to the company where they work. So, the aspect of character building in human resources in the company becomes so important, and needs to be given a point of attention. Qualified human beings will create their own achievements for themselves and the wider community in general. Local wisdom can be 
used as an alternative in building the character of human resources. Local wisdom is considered good and suitable as an alternative to build the character of human resources because local wisdom is the noble values possessed by each region which are upheld by the values and meanings contained therein. Similar to other regions, in Bali there is also local wisdom that can be used as a model to build the character of human resources. The approach of Balinese local wisdom related to building the character of human resources is through the concept of Tri Kaya Parisudha.

The concept of Tri Kaya Parisudha as one of the local wisdoms in Bali is a philosophy of life to make this life harmonious. Based on the concept of Tri Kaya Parisudha, there are three activities that must be controlled and harmonized with each other, namely thoughts (manacika), words (wacika), and actions (kayika) (Yuliandari, 2016). Harmony between thoughts, words, and actions is an indicator of HR character. The attitude of controlling these three activities in the teachings of Hindus is based on a strong belief in the law of karmaphala. The law of karmaphala is the law of cause and effect or reaction action, which means that when a human being is able to control these three types of activities in a positive direction, then positive results will be obtained, and vice versa. Therefore, belief in the law of karmaphala becomes the foundation for humans to control the three types of activities contained in the teachings of Tri Kaya Parisudha.

Human achievement in life, including in organizational life, is determined by the three main types of behavior. Thus, what distinguishes one individual from another, which causes an organization to be famous and or known is because of the character and quality of the three human behaviors. This statement is implicitly stated in the Book of Sarasamuscaya, verse 77, which states as follows:

"What causes a person to be known is his behavior, his thoughts, his words, that is what a person pays attention to. Therefore, the good are also accustomed to actions, words and thoughts."

Every religion teaches that mankind should abstain from evil deeds and sinful acts and get rid of envy/envy. Humans are also taught to always do good (dharma), with kind words (without offending others), and always do good. This statement is in line with the teachings contained in the Tri Kaya Parisudha concept, namely to always think good, say good, and do good. Thus, by creating harmony and harmonization within oneself, a good individual character will be created.

So, starting from the phenomenon above, the researcher wants to examine more deeply through the research title "Building Character Perspective of Local Wisdom in the Press Industry".

\section{THEORITICAL REVIEW}

\section{HR Character}

Organizations large or small, profit-oriented and non-profit, in carrying out their daily activities as a series in achieving organizational goals, always strive to utilize all their resources to the maximum extent possible, in order to provide maximum contribution to the organization. Of the several resources owned by an organization, HR is the most important 
resource, whose existence, character and quality will greatly determine the progress of an organization.

Character is the values of human behavior related to God Almighty, oneself, fellow human beings, the environment, and nationality which are manifested in thoughts, attitudes, feelings, words, and actions based on religious norms, laws, manners, culture. , and customs (Muslich, 2011). Character can be interpreted as a basic value that builds a person's personality, formed both due to the influence of heredity and environmental influences, which distinguishes him from others, and is manifested in his attitudes and behavior in everyday life (Muchlas and Hariyanto, 2011).

In general, building the character of an employee must start from emphasizing the company's cultural values on them. Where the values of corporate culture must be used as a basis for them to do their work. This is in order to create human resources who have competence and character, so that they are able to adapt in all situations and conditions with maximum results for the company. In essence, humans or an organization in their lives are determined by three qualities of behavior, namely thoughts, words and actions (Gorda, 1996). The elements of thoughts, words and actions in the concept of local culture in Bali are known as Tri Kaya Parisudha. Tri Kaya Parisudha are the three most essential potentials in humans and greatly affect the character of HR in living their daily lives.

\section{Tri Kaya Parisudha Local Wisdom}

Local wisdom is the capital of the formation of the noble character of a nation. This noble character is the character of the nation who always acts on the basis of full selfawareness and self-control. One of the values of local wisdom that is developing and has the potential to be developed, especially in the realm of Balinese culture, is the value contained in the Tri Kaya Parisudha philosophy. In the Tri Kaya Parisudha philosophy, humans are taught to always think well, say good, and do good. This philosophy is very precisely synergized with the concept of universal character education which teaches individuals about ways of thinking and behaving that are characteristic of each individual to be able to live and work together, both within the family, community, nation and state (Suyanto, 2011).

An organization is considered to have a good image if an organization places its corporate image development on: 1) the ability of the organization concerned to attract highquality human resources, 2) the ability of the organization concerned to maintain high-quality human resources, and 3) the ability of the organization to concerned with growing one's pride in working in the organization (Gorda, 1996). Tangible quality human resources can be seen from the level of education and physical health, but intangible can be seen through aspects of their behavior in everyday life.

In practice in everyday life, human achievement in life including in organizational life is determined by three main types of behavior, namely in accordance with the concept of Tri Kaya Parisudha, namely thinking behavior (manacika), speaking or communicating behavior (wacika), and physical activity behavior. or technical (kayika). The concept of Tri Kaya Parisudha are the three most essential potentials that exist in humans which greatly influence the quality of human resource behavior in achieving individual goals and organizational goals (Gorda, 1996). At least, local wisdom can appear in the aspects of: 1) thinking, 2) attitude, 
and 3) behavior. These three things are almost difficult to separate, if all three are unequal, then the local wisdom will fade (Wagiran, 2012). Based on this, it is considered relevant if the Tri Kaya Parisudha concept is used as a model for the formation of the quality of human resources, because the values and meanings contained in it can explicitly be used as a national and universal value system.

Thinking behavior (manacika) a model of Rationality and Creativity. Manacika is the quality of thinking behavior in humans (quality of thinking). By using the human mind gain meaning in his life. It is said that way because (1) through the human mind it can distinguish between good and bad deeds, (2) the mind becomes the source of stimulation for all human actions or behavior in life, and (3) the mind plays a major role in human life. (Gorda, 1996). Hindu belief in the law of karma phala sraddha (law of cause and effect) is the main basis for humans to control themselves in the process of thinking. Humans think also means, he is trying to think creatively in order to solve all forms of problems and challenges in his life. The creativity that is formed is a source of innovation which is closely related to the human ability to be adaptive to dynamic and pragmatic human life. Rational thinking, creative and full of initiative are needed in modern life, in the teachings of Hindu religion these values are contained in the sacred Vedic literature. Hindus believe that these three attitudes function as a driving force and frame of reference for Hindus in living life in the era of globalization, because humans who have such behavioral qualities, according to Hinduism, will succeed in facing various challenges and obstacles of life in the era of globalization.

\section{Behavior of speaking or communicating (wacika) a model of Human Relations Ability}

Humans are essentially social creatures, which means they need interaction in their lives. The results of the new human thought will be meaningful and useful for their own life or organization if the human is doing good communication (wacika). Communication is very useful for humans to convey all forms of intent and purpose to other people. Communication has a very important role in human life, especially in an organization. The role of positive communication (wacika) according to the beliefs of Hindus is (1) words cause success in life, (2) words cause someone to meet failure in life, (3) words cause someone to get something as a source of success. life, and (4) words cause a person to have good relations or friends (Gorda, 1996). Improved sense of communication (wacika) means improving the quality of a person in reciprocal relationships with various parties for the achievement of goals. The communication process carried out by a person must avoid offence and misunderstanding. This is because these two things are the source of conflicts, tensions, and even discoordination in life or organization. In the teachings of Hinduism, it is also believed to be faithful to words or promises (satya discourse). The teachings of this satya discourse remind people to always control themselves in relation to words or promises to other people and society. Based on this, it can be concluded that the quality of speaking or communicating positively from someone, especially someone who acts as a leader in the organization, will have a positive impact on the organization in the form of: (1) growing and developing human relationships so as to avoid tension, conflict, show off feelings, absenteeism, frustration, and similar behaviors, (2) increased business productivity, and (3) the development of human relations with the community environment such as customers, followers, and relationships in business activities (Gorda, 1996). 


\section{Physical or technical behavior (kayika) of a Technical Ability Model}

The kayika aspect is the potential possessed by humans which is closely related to one's ability to manifest in a real or technical way what is thought and said (decided) in organizational life. Technical ability in question is the ability to carry out something to achieve goals in a positive way. The forms of technical ability include: being able to use equipment, procedures, the ability to use science and technology and other similar activities. By improving the quality of human resources within the organization, the organization will increase the ability to produce goods or services that will be very beneficial for improving the welfare of both individuals and the welfare of the wider community.

The core character of Tri Kaya Parisudha which consists of thinking well (Manacika), saying good (Wacika) and doing good (Kayika) is a good character. Good character involves moral knowledge (moral knowing), moral feelings (moral feeling), and moral action (moral acting) (Lickona, 2012). The values of Tri Kaya Parisudha need to be instilled in the company, because the company is a place for developing intelligent and character human resources (smart and character building). The formation of the core character of Tri Kaya Parisudha in the company is very important.

Table 1. Character values based on the teachings of Tri Kaya Parisudha

\begin{tabular}{lll}
\hline Aspect & Parisudha's Tri Kaya Values & Impl IKASI in life \\
\hline Manacika & $\checkmark \cdot$ No prejudice, suspicion, and bad thinking. & $\checkmark \cdot$ Berp ikir positive \\
(Mind) & $\checkmark \cdot$ Thinking Causality. & $\checkmark \cdot$ Thinking inductive-deductive \\
& $\checkmark \cdot$ Mengha rgai views of others. & $\checkmark \cdot$ Resistance mental, patient, \\
& $\checkmark \cdot$ T angguh face trials and challenge & $\checkmark \cdot$ Discipline \\
& $\quad$ problems & $\checkmark \cdot$ Thinking Analytical, Reason and \\
& $\quad$ in the nation & Sistema tis \\
& & $\checkmark \cdot$ Me nghargai others \\
\hline Wa cika & $\checkmark \cdot$ Do not say rude and hurt other people & $\checkmark \cdot$ Do not say rude and hurt or ang \\
(saying) & $\checkmark \cdot$ Do not slander and lie. & other \\
& $\checkmark \cdot$ Dare, so pan and polite in asking the views, & $\checkmark \cdot$ Do not malign d an lied \\
& $\quad$ questions and arguments. & $\checkmark \cdot$ Bold, courteous and polite in \\
& & asking the views, questions and \\
& $\checkmark \cdot$ Do not do the physical and psychological & $\checkmark \cdot$ Doing good and right \\
& $\quad$ violence & $\checkmark \cdot$ sed aga environmental \\
& $\checkmark \cdot$ Do not get anything by way of cheating & hygiene \\
\hline Kayika & $\checkmark \cdot$ save money, wakt u, and power & $\checkmark \cdot$ Doing honest \\
(do it) & $\checkmark \cdot$ Work together & $\checkmark \cdot$ Care for the environment (do not \\
& $\checkmark \cdot$ Ad aptif & waste any) \\
& $\checkmark \cdot$ Responsible & $\checkmark \cdot$ Responsible \\
& $\checkmark \cdot$ Care for the environment & $\checkmark \cdot$ B ekerja same \\
& $\checkmark \cdot$ Always helping others & $\checkmark \cdot$ Concerned with ses ama \\
& $\checkmark \cdot$ Respect fellow & \\
& Sunated &
\end{tabular}

Source : Research Sunariani et al (2016)

This is in line with Mahatma Gandhi who said that keep your thoughts positive, because your thoughts will become your words. Watch your words, for they will become your actions. Watch your behavior, because it will turn into your habit. Keep your habits positive, because they will be the value of your life. Keep the value of your life to stay positive, because it will be the goal of your life. Based on the results of the field study, the 
character values that can be developed in each of Tri Kaya Parisudha's core characters are briefly presented in Table 1.

Based on Table 1. it is very good if we implement the teachings of Tri Kaya Parisudha in daily life. If we are able to control our thoughts, words and actions, surely harmony in life will be realized.

\section{RESEARCH METHODS}

In this study, qualitative research methods are used, meaning that in this research it is useful to find knowledge that is contained or contained in a particular culture or community. Qualitative research is research that is used to examine the condition of natural objects where the researcher is the key instrument (Sugiyono, 2018).

This research was conducted at PT. Bali Post is located at Jl. Kepundung No. 67A Denpasar. The informants in this study were the editor-in-chief, managers, editors, journalists and partners of the Bali Post, the data were collected through purposive sampling method. In this study the data collected consisted of primary data and secondary data. Primary data, which is the main information in the research, includes all qualitative data obtained through observation and in-depth interviews. Secondary data, is data obtained through reference books in the form of notions and theories that have to do with the problem being studied. The data collection procedure in this study is by using procedures such as observation, interviews and documentation. (1) Observation, observation is the first step in conducting research, observations are made to find out in detail about the location and condition of the place (Bali Post) that will be examined both in terms of leaders, managers, and employees. (2) In-depth Interview, interviews as an assessment tool are used to find out opinions, aspirations, and beliefs. Interview activities were carried out directly, namely holding questions and answers through triangulation of sources with informants, namely the editor-in-chief, managers, employees and Bali Post partners. (3) Documentation, documents can be in the form of writing, pictures, or monumental works of someone. In this study, several documents were collected that can support information from informants and research interests.

While the data analysis in this study, Milles and Hubberman (in Sugiyono, 2018) explain that data analysis is the steps to process research findings that have been transcribed through a data reduction process, namely the data is filtered and compiled again, presented, verified and then made conclusions.

\section{RESULTS AND DISCUSSION}

In the world of the press, it is recognized the importance of character in efforts to develop human resources in a company. Various studies and facts show that a developed nation is a nation with a strong character. These character values are values extracted from culture that are in harmony with the characteristics of the local community (local wisdom).

This is supported by the results of an interview with Mr. I Wayan Dira Arsana who is the Chief Editor of PT. Bali Post. Wednesday, April 22, 2020 at 10.00 WITA at the PT. Bali Post Jl. Kepundung No. 67A with resource persons. He is 50 years old, and has worked since 1994 until now, stating that:

\footnotetext{
"In building or developing the character of human resources in the press industry, it is very important, especially since the Bali Post's commitment to Balinese culture is very high. Culture also teaches how we must form a good character. One form of work discipline in Bali Post in
} 
shaping and building the character of its human resources, especially journalism, is always guided by the rules of journalistic ethics including cultural ethics, ethics of local wisdom because it is very important to be implemented in journalistic work. Every company has a culture that is used as a guide in running the company, the context of the Bali Post culture is Tri Kaya Parisudha, before work of course employees pray every morning it is a form of prostration to Ida Sang Hyang Widhi Wasa, maintaining a harmonious work environment between friends by speaking politely, and not to offend co-workers, other examples are respecting the leadership, respecting co-workers with humane behavior, besides always participating in maintaining the cleanliness of the work environment, doing tirta yatra, and so on. Tri Kaya Parisudha is very important in the world of the press, therefore employees and especially the journalist profession must be considered. You do this by recruiting qualified employees, such as having to pass a competency test. The signs regarding journalistic ethics must be paid close attention to because that is what is used as a guide in behavior, if there is an error then the employee will be evaluated. So when a journalist carries out his profession, the journalist must be skilled and show his identity as a journalist with character. So that the informant will also know that what he is talking about will become public consumption. So it is not permissible to play with sources for the hidden interests of the journalists themselves, because by playing with someone, we will get karma. Every word and action we do is always balanced with karma. Therefore, we need to think about the words and actions we take, so as not to get the karma we don't want."

Furthermore, the results of the interview with Mr. I Putu Gugiek Savindra who is the Editor of the Bali Post, who is responsible for the daily working mechanism of the editor. $\mathrm{He}$ is 37 years old, and has been working since 2009 until now. The interview was conducted on Wednesday, April 22, 2020 at 10.35 WITA at the PT. Bali Post J1. Kepundung No. 67A, regarding the importance of building or developing character in the press industry, states that:

"In building and developing character in a company, it is very important, because character will affect the product results of a company. If from the start the product has good character, good human resources, it will produce good products too. The way Bali Post builds its human resources, usually there will be trainings that are carried out according to Bali Post standards, such as training abroad for training, seminars to increase insight and knowledge in the fields that each person is involved in. In addition to outbound training, Bali Post also has internal training as well as sharing with seniors who have been in press work earlier, when doing work there is also an evaluation carried out where when employees make mistakes, they are expected to be able to correct what went wrong so that it doesn't happen again. again the error. Character with the application of Tri Kaya Parisudha is very important because Tri Kaya Parisudha can be the basis for behaving in the Bali Post, because by behaving, saying, and thinking well later when all of that can be implemented/done well, it will certainly make the Bali Post company better. In general, the company is also good and can spread its kindness to the surrounding community, especially the readers of the Bali Post daily. We as religious people certainly know the existence of karma phala, therefore we must always guard our words and behavior so as not to hurt someone's heart."

In choosing and establishing business partners in a business, it is not an easy thing. Wrong in making choices, will disrupt business programs, finance, maybe even the future of the company. For that, choose the right business partner for the company. Bali Post as a media company that has been around for a long time and with good character certainly has the right partners.

Bali Post's partners who have given the best brand/award are from the National News Agency (LKBN) ANTARA Bureau of Bali in the form of a Tjatranata certificate where Bali Post is the partner who has provided the best cooperation so far. The interview was conducted with Mr. Edy M Ya'Kub on Monday, August 10, 2020, at 19.00 WITA. He is the Head of the 
Bali Bureau of LKBN ANTARA Bureau who has worked for about 24 years at ANTARA Bali Bureau's LKBN, his age is 55 years. The results of the interview regarding the collaboration carried out by LKBN BETWEEN the Bali Bureau and the Bali Post and the aim of giving the best brand/award to Bali Post, according to Mr. Edy stated that:

\begin{abstract}
"LKBN ANTARA as the National News Agency has the "main task" of serving mass media in the form of news content, photos, videos, and infographics. Nationally, ANTARA serves hundreds of mass media throughout Indonesia, while for LKBN ANTARA Bali Bureau serves 15-16 mass media, both print and onlinelonline media, including the print media "Bali Post" which is the largest and historic media in Bali. Bali Post is a good partner, professional, and very communicative. The Bali Post leadership did not hesitate to provide evaluations, input, and suggestions for ANTARA's services to the media in a very friendly and communicative way. The relationship between the ANTARA News Agency and the Bali Post has been around for 50 years. The cooperation between LKBN BETWEEN the Bali Bureau and the Bali Post which lasted for 50 years shows that trust and good relations have been tested. So with that trust, Bali Post deserves an award as a partner who provides the best cooperation."
\end{abstract}

Next are the results of interviews with other Bali Post partners which were conducted on Monday, 18 May 2020 at 09.00 WITA, namely with Mrs. Anik Nurhaini who is a Public Relations Officer from the International Bali University (UNBI), she has worked for 5 years since the beginning of the UNBI campus was established in 2015. UNBI chose Bali Post as a working partner according to Mrs. Anik stating that:

"UNBI has cooperated since the establishment of the campus for about 5 years. Most of the cooperation that is done is advertising, promotion / authorial. Why Bali Post, because if you look at the length of time the company was founded, Bali Post is the oldest company, most of the companies we saw used Bali Post (large companies, government agencies) although many other newspapers entered the press world, but what we saw Bali Post still remains in the hearts of large agencies and companies. Besides that, why Bali Post, because we see the market, so the hope is that the advertisements posted/published will also be seen by the reader. Every employee who comes to look for news is different, but in general everyone who comes here has a good attitude, polite, friendly, say hello. Since the beginning of working together, Bali Post has been like that. So when viewed from the Tri Kaya Parisudha concept, Bali Post has reflected this behavior, until now we and Bali Post are still working well and no offense has occurred, so far all who have come here are kind and polite in their words and actions. behave in accordance with the Tri Kaya Parisudha. The suitability of the news is also in accordance with what is expected, nothing is made up. What we saw was the character/culture being grown there was good, the employees at Bali Post were friendly and kind. In addition, Bali Post also provides convenience for the customers themselves."

Based on the results of interviews with informants, the results obtained are that the informants believe that in building character through local wisdom, both from the aspect of thoughts, words, and actions, it must be based on an attitude that always remembers (eling) with the law of karmaphala, namely the law of cause and effect or the law of action and reaction. or more universally known as "what we sow, that's what we reap". In building character, the point of everything is thoughts because through thoughts will represent what we do and what we will say. With good thoughts, people will say good things too. With good thoughts, people will do good too. Thus, as humans who are given advantages in the context of reason or thought, humans should take advantage of these advantages for positive and beneficial things for fellow human beings. Because, in the teachings of all religions, it is always emphasized to do good, benevolence, and justice. That's why one must always control and control his mind, keep his movement and his mind calm, because only with a controlled mind, calm and calm can one say and do good and right. In other words, the thought must be good, the word must be good and the deed must also be good. Thoughts, words and good deeds must always be used as guidelines in navigating this life, so that harmony, tranquility and peace are maintained in society. According to research from Wagiran (2012), stating that the values of local wisdom are not an obstacle to progress in the global era, but become an 
extraordinary transformational force in increasing human resources as a capital for a nation's competitive and comparative advantage. Therefore, extracting the values of local wisdom is a strategy in an effort to build character. Local wisdom itself is passed down from generation to generation and maintained, not only because of its functionality as a recipe for action, but also because it is seen from a pragmatic point of view so that it has use value in the context of realizing a harmonious society and company employees. The values and meanings of the Tri Kaya Parisudha concept are values that apply universally and are taught by almost all religions, but in Balinese society, this concept can be used as a reference in carrying out human activities, especially in the behavioral aspect.

Hasil wawancara ini dipadukan dengan hasil pengamatan atau observasi dari kegiatan sehari-hari. Pengamatan yang dilakukan berupa pengamatan tentang penyampaian gagasan dan ide, cara berkomunikasi dengan teman, cara memperlakukan teman dan pimpinan, serta melalui informan ketika diluar kantor saat peliputan dengan mitra kerja. Rata-rata, karyawan dalam menjalin kerja sama dengan mitra kerja memiliki karakter yang berbeda. Hal ini tentu sangat terkait dengan budaya lokal yang dimiliki oleh karyawan. Karyawan yang ada di Bali Post hampir semua karyawan berasal dari Bali.

Karyawan Bali Post menyadari bahwa didalam melakukan suatu pekerjaan, baik itu berupa tindakan yang akan diambil saat melakukan pekerjaan haruslah dipikirkan terlebih dahulu dampaknya, baik itu dampak positif maupun negatifnya. Hal ini tentu mengacu pada hukum karmaphala yang diyakini oleh umat Hindu, yaitu hukum sebab akibat atau aksi reaksi, sehingga menjadikan karyawan agar berpikir, berkata atau berkomunikasi, dan berbuat atau bertindak sesuai ajaran Tuhan, selain itu karyawan Bali Post juga harus ingat dengan pedoman etika jurnalistik yang diterapkan dan digunakan dalam melakukan pekerjaan sebagai Pers. Karyawan menyadari bahwa sebelum melakukan suatu tindakan, harus dan wajib dipikirkan terlebih dahulu, agar apa yang ada dalam pikiran dapat dikomunikasikan dengan baik sehingga memberikan dampak yang baik pula. Selain pikiran yang baik itu, dari proses komunikasi yang baik ini, akan mampu menciptakan suatu tindakan yang baik pula. Melalui ketiga sikap dasar ini serta kepercayaan yang mendasari akan adanya hukum karmaphala, karyawan akan mampu menciptakan sinergi yang selaras dan harmonis dengan sesame baik itu pimpinan, teman, maupun mitra kerja. Maka dari itu, berdasarkan atas hasil observasi yang telah dilakukan, serta diklarifikasi melalui informan, konsep karakter melalui pendekatan Tri Kaya Parisudha mampu untuk dijadikan suatu model dalam menilai karakter SDM.

Dalam dunia pers, sudah sepantasnya menekankan pada karakter yang baik, karena dampaknya adalah kepada masyarakat itu sendiri. Masyarakat yang melihat bahwa nilai (values) yang dianggap baik adalah nilai yang tercermin dari isi berita yang di buat. Peran karakter pers yang baik dalam pikiran, perkataan dan perilaku bertanggung jawab ini serta tetap memegang teguh nilai budaya perlu terus diperhatikan, diupayakan dan dikembangkan dalam bentuk interaksi positif antara surat kabar daerah, pemerintah, dan masyarakat sehingga terwujud peran aktif surat kabar lokal dalam mendukung pembangunan, menyebarkan informasi yang objektif dan edukatif, melakukan kontrol sosial, menyalurkan aspirasi rakyat, memperluas komunikasi dan peran serta positif masyarakat sehingga dampaknya pun akan baik dimata masyarakat pembaca itu sendiri 


\section{CONCLUSION}

Based on the explanation above, it can be concluded that the local cultural approach of Tri Kaya Parisudha as a model for building the character of human resources, while the values and meanings contained in it are aspects of the mind (manacika), aspects of communication or speaking (wacika), and aspects of attitude. or act (kayika) that is good is very relevant when applied in everyday life. The concept of Tri Kaya Parisudha based on the belief in the law of karmaphala, namely the law of cause and effect or the law of action and reaction will make humans better understand their identity as humans who are gifted with more abilities than other creatures created by God. Today's human character should be judged, without neglecting the aspect of the assessment in the form of numbers or numerics. Thus, Tri Kaya Parisudha is deemed worthy to be used as a measuring tool in assessing the character of HR in a social and organizational life.

\section{REFERENSI}

Gorda, I G. Ngr. (1996). Etika Hindu dan Perilaku Organisasi. Denpasar: PT. Widya Aksara Nasional.

Lickona, T. (2012). Mendidik Untuk Membangun Karakter "Bagaimana Sekolah dalam Memberikan Pendidikan Tentang Sikap Hormat dan Bertanggung jawab" judul asli: Educating for Character: How Our Schools Can Teach Respect And Reponsibility. Jakarta : PT. Bumi Aksara.

Muchlas, S. \& Hariyanto. (2011). Konsep dan Model Pendidikan Karakter. Bandung: PT. Remaja Rosdakarya.

Muslich, M. (2011). Pendidikan Karakter: Menjawab Tantangan Krisis Multidimensional. Jakarta: Bumi Aksara.

Sugiyono. (2018). Metode Penelitian Kuantitatif Kualitataif. Bandung: Alfabeta.

Sunariani, N. N., Yuliandari, N. K., Trisnadewi, N. K. A., Nurkariani, N. L. (2016). Kearifan Lokal Tri Kaya Parisudha Sebagai Model Pembentuk Kualitas Sumber Daya Manusia. STIE Satya Dharma Singaraja, Universitas Pendidikan Nasional.

Suyanto. (2011, November 2019). Urgensi Pendidikan Karakter. Diakses dari http://mandikdasmen.kemendiknas.go.id/web/pages/urgensi.html.

Wagiran, W. (2012). Pengembangan Karakter Berbasis Kearifan Lokal Hamemayu Hayuning Bawana (Identifikasi Nilai-nilai Karakter Berbasis Budaya). Jurnal Pendidikan Karakter. (3).

Yuliandari, N. K., Sunita, D., Sastrawan, D. P. R., Wiradnya, I.K.R. (2016). Pendekatan Budaya Lokal Tri Kaya Parisudha dalam Membentuk Mental dan Karakter. STIE Satya Dharma Singaraja, Universitas Pendidikan Nasional. 